\title{
Hydroxide Degradation Pathways for Substituted Benzyltrimethyl Ammonium: A DFT Study
}

\author{
Hai Long and Bryan S. Pivovar, \\ National Renewable Energy Laboratory, Golden, Colorado 80401, USA
}

\begin{abstract}
The stability of cations used in the alkaline exchange membranes has been a major challenge. In this paper, degradation energy barriers were investigated by density functional theory for substituted benzyltrimethyl ammonium (BTMA ${ }^{+}$) cations. It was found that electron-donating substituent groups at meta-position(s) of the benzyl ring could result in increased degradation barriers. However, after investigating more than thirty substituted $\mathrm{BTMA}^{+}$cations, the largest improvement in degradation barrier found was only $6.7 \mathrm{~kJ} / \mathrm{mol}$. This suggests a modest $(8 \times)$ improvement in stability for this type of approach may be possible, but for anything greater other approaches will need to be pursued.

(C) The Author(s) 2014. Published by ECS. This is an open access article distributed under the terms of the Creative Commons Attribution Non-Commercial No Derivatives 4.0 License (CC BY-NC-ND, http://creativecommons.org/licenses/by-nc-nd/4.0/), which permits non-commercial reuse, distribution, and reproduction in any medium, provided the original work is not changed in any way and is properly cited. For permission for commercial reuse, please email: oa @electrochem.org. [DOI: 10.1149/2.0041501eel] All rights reserved.
\end{abstract}

Manuscript submitted September 5, 2014; revised manuscript received October 22, 2014. Published November 1, 2014. This was Paper 1263 presented at the Cancun, Mexico, Meeting of the Society, October 5-9, 2014.

The alkaline fuel cell (AFC) is one of the oldest types of fuel cells ${ }^{1}$ and has the advantage of enablement of non-precious catalysis. ${ }^{2}$ However, application of this type of fuel cell has still been limited due to carbonate precipitate formed on the electrodes when carbon dioxide from air reacts with liquid alkaline electrolytes (typically $\mathrm{KOH}){ }^{3,4}$ Research in this area has seen increased interest in recent years because of the development of the alkaline membrane fuel cell (AMFC). ${ }^{5,6}$ In an AMFC, an anion exchange membrane (AEM) is used between the electrodes to allow hydroxide $\left(\mathrm{OH}^{-}\right)$to transport across the membrane and prevent carbonate precipitate from forming. One key concern for these systems is the stability of cations that are attached to the polymer backbone of the membrane and are susceptible to chemical attack and degradation by hydroxide. ${ }^{6-8}$

Benzyltrimethyl ammonium $\left(\mathrm{BTMA}^{+}\right)$cation has been the most commonly employed cation in AEMs and has been investigated extensively for its application in AMFC. ${ }^{9-16}$ Previous experimental measurements had shown that the concentration of unsubstituted BTMA ${ }^{+}$ cation decreased by $\sim 10 \%$ within 29 days in $5 \mathrm{~mol} / \mathrm{L} \mathrm{NaOH}$ at $80^{\circ} \mathrm{C}^{10}$ Our most recent experimental studies have shown even longer lifetimes at $80^{\circ} \mathrm{C}$, while meaningful degradation rates were observed particularly when tests were performed at elevated temperatures (above $\left.120^{\circ} \mathrm{C}\right) .{ }^{17}$ The two primary degradation reactions for $\mathrm{BTMA}^{+}$are $\mathrm{OH}^{-}$attack via benzyl $\mathrm{S}_{\mathrm{N}} 2$ and methyl $\mathrm{S}_{\mathrm{N}} 2$ pathways: ${ }^{18,19}$

$$
\mathrm{C}_{6} \mathrm{H}_{5} \mathrm{CH}_{2} \mathrm{~N}^{+}\left(\mathrm{CH}_{3}\right)_{3}+\mathrm{OH}^{-}=\mathrm{C}_{6} \mathrm{H}_{5} \mathrm{CH}_{2} \mathrm{OH}+\mathrm{N}\left(\mathrm{CH}_{3}\right)_{3} \text {, }
$$
and

$$
\mathrm{C}_{6} \mathrm{H}_{5} \mathrm{CH}_{2} \mathrm{~N}^{+}\left(\mathrm{CH}_{3}\right)_{3}+\mathrm{OH}^{-}=\mathrm{C}_{6} \mathrm{H}_{5} \mathrm{CH}_{2} \mathrm{~N}\left(\mathrm{CH}_{3}\right)_{2}+\mathrm{CH}_{3} \mathrm{OH} \text {. }
$$

Our density functional theory (DFT) calculations resulted in transition state (TS) barriers $\left(\Delta \mathrm{G}^{\neq}\right)$for $\mathrm{BTMA}^{+}$benzyl and methyl $\mathrm{S}_{\mathrm{N}} 2$ pathways of $97.5 \mathrm{~kJ} / \mathrm{mol}$ and $105.0 \mathrm{~kJ} / \mathrm{mol}$ respectively at $160^{\circ} \mathrm{C}$ and $101.325 \mathrm{kPa}^{20}$ (TS structures shown in Fig. S1). Thus, the benzyl $\mathrm{S}_{\mathrm{N}} 2$ pathway is predicted to be the dominant degradation pathway for $\mathrm{BTMA}^{+}$, and has been confirmed experimentally. ${ }^{17}$

In order to explore improvements to the stability of $\mathrm{BTMA}^{+}$, a straightforward method is to add substituent groups to the benzyl ring of $\mathrm{BTMA}^{+}$. In this manuscript, $\mathrm{BTMA}^{+}$cations with different substituent groups at different positions were modeled and their degradation barriers were calculated using DFT in order to search for simple chemical modifications that could potentially result in dramatic changes in stability.

The computational results presented here are best viewed in terms of the relative comparison in energy barriers between different $\mathrm{BTMA}^{+}$substitutions. For this reason, most of our discussion

\footnotetext{
*Electrochemical Society Active Member.
}

${ }^{\mathrm{z} E}$-mail: bryan.pivovar@nrel.gov and the Figures presented focus on $\Delta \Delta \mathrm{G}^{\neq}$, the change of $\Delta \mathrm{G}^{\neq}$between substituted and unsubstituted $\mathrm{BTMA}^{+}$. These relative changes in $\Delta \mathrm{G}^{\neq}$can show (relative) changes in stability without necessarily having an accurate absolute $\Delta \mathrm{G}^{\neq}$. The absolute certainty of DFT calculations can only be assessed with experimental validation (work that is currently being undertaken in our labs for several of the cations presented here).

\section{Method}

The detailed method used for DFT calculations are described in the literature. ${ }^{20}$ In short, Gaussian $09(\mathrm{G} 09)^{21}$ was used to optimize the reactants and TS structures by B3LYP 22 method, 6-311++G(2d,p) basis set, and PCM solvation model. During the geometry optimization calculations, no molecular symmetry was applied so that asymmetric structures could be explored. The free energies at $160^{\circ} \mathrm{C}$ and $101.325 \mathrm{kPa}$ for the reactants and TS were then calculated based on the optimized structure. $\Delta \mathrm{G}^{\neq}$was then obtained by comparing the total free energies of the ground states of reactants (cation $+\mathrm{OH}^{-}$) with the free energy of the TS state. ${ }^{20} \Delta \Delta \mathrm{G}^{\neq}$was calculated from the difference of $\Delta \mathrm{G}^{\neq}$values between the substituted and unsubstituted $\mathrm{BTMA}^{+}$cations.

\section{Results}

Neutral substituents. $-\Delta \mathrm{G}^{\neq}$values of benzyl $\mathrm{S}_{\mathrm{N}} 2$ and methyl $\mathrm{S}_{\mathrm{N}} 2$ for substituted $\mathrm{BTMA}^{+}$cations at different positions on the benzene ring (Fig. 1) were obtained and presented in Table I. Five electrondonating substituent groups and one electron-withdrawing substituent group, i.e., $-\mathrm{NO}_{2}$, were investigated. For each substituent, single substitutions at ortho, meta, and para positions (position 2, 3, and 4) and double substitutions at the meta positions (position 3 and 5) were calculated.

Fig. 2 illustrates the $\Delta \Delta \mathrm{G}^{\neq}$of the substituted $\mathrm{BTMA}^{+}$cations. For the methyl $\mathrm{S}_{\mathrm{N}} 2$ reaction (Fig. 2a), the $\Delta \Delta \mathrm{G}^{\neq}$are between -12.5 $\sim+12.5 \mathrm{~kJ} / \mathrm{mol}$. The $\Delta \Delta \mathrm{G}^{\neq}$values for $-\mathrm{N}\left(\mathrm{CH}_{3}\right)_{2}$ substitutions at all positions are $\geq 0$ and the $\Delta \Delta \mathrm{G}^{\neq}$values for all $-\mathrm{NO}_{2}$ substitutions are $<0$. The $\Delta \Delta \mathrm{G}^{\neq}$for other substituted cations are either larger or smaller than 0 , depending on the substitution positions. The largest $\Delta \Delta \mathrm{G}^{\neq}$is $11.3 \mathrm{~kJ} / \mathrm{mol}$ from the para $-\mathrm{N}\left(\mathrm{CH}_{3}\right)_{2}$ substitution. The results obtained in Fig. 2a are generally consistent with what could be expected from the electron donating/withdrawing characteristics of the substituent groups and their location(s).

For the benzyl $S_{N} 2$ reaction (Fig. $2 b$ ), the $\Delta \Delta G^{\neq}$compared to unsubstituted $\mathrm{BTMA}^{+}$are between $-13 \sim+7 \mathrm{~kJ} / \mathrm{mol}$. The largest positive $\Delta \Delta \mathrm{G}^{\neq}$is $6.7 \mathrm{~kJ} / \mathrm{mol}$ from the double-meta substituted $-\mathrm{NH}_{2}$ 


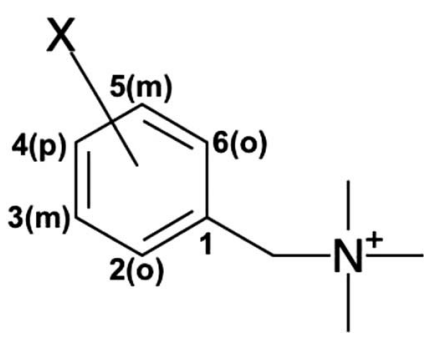

Figure 1. Substituted $\mathrm{BTMA}^{+}$cations investigated this section. $\mathrm{X}=-\mathrm{OH}$, $-\mathrm{OCH}_{3},-\mathrm{CH}_{3},-\mathrm{NH}_{2},-\mathrm{N}\left(\mathrm{CH}_{3}\right)_{2}$, and $-\mathrm{NO}_{2}$.

Table I. $\Delta G^{\neq}$values in $\mathrm{kJ} / \mathrm{mol}$ of benzyl $S_{N} 2 /$ methyl $S_{N} 2$ pathways for the unsubstituted and substituted $\mathrm{BTMA}^{+}$cations at $160^{\circ} \mathrm{C}$ and $101.325 \mathrm{kPa}$. The ones with a larger $\Delta \mathrm{G}^{\neq}$than the unsubstituted BTMA $^{+}$are shown in bold.

\begin{tabular}{|c|c|c|c|c|}
\hline Substitution Position & $2(0)$ & $3(\mathrm{~m})$ & $4(\mathrm{p})$ & $3 \& 5$ \\
\hline No substitution & & $97.5 / 1$ & 105.0 & \\
\hline$-\mathrm{OH}$ & $84.5 / 105.0$ & $\mathbf{9 7 . 9 / 1 0 3 . 3}$ & 97.9/106.7 & 102.5 \\
\hline$-\mathrm{OCH}_{3}$ & 102. & 95.8/107.1 & $99.6 /$ & 99. \\
\hline$-\mathrm{CH}_{3}$ & $97.1 / \mathbf{1 0 5 . 9}$ & 100.0/104.2 & $90.8 / 97.5$ & $102.9 / 109.2$ \\
\hline$-\mathrm{NH}_{2}$ & $92.0 / \mathbf{1 0 6 . 3}$ & 96.7/105.9 & $96.2 / \mathbf{1 1 0 . 0}$ & $104.2 / 106.3$ \\
\hline$-\mathrm{N}\left(\mathrm{CH}_{3}\right)_{2}$ & $100.8 / 110.9$ & $102.5 / 105.0$ & $92.0 / \mathbf{1 1 6 . 3}$ & $104.2 / 112.5$ \\
\hline$-\mathrm{NO}_{2}$ & $86.6 / 101.7$ & $90.4 / 101.3$ & $90.4 / 102.1$ & $85.8 / 92.9$ \\
\hline
\end{tabular}

and $-\mathrm{N}\left(\mathrm{CH}_{3}\right)_{2}$. Again, the $\Delta \Delta \mathrm{G}^{\neq}$values for all $-\mathrm{NO}_{2}$ substitutions are less than 0 . For all of the substitutions studied, the $\Delta \mathrm{G}^{\neq}$values of benzyl $S_{N} 2$ are less than the methyl $\Delta \mathrm{G}^{\neq}$values, predicting that the methyl $S_{N} 2$ reaction is never the preferred degradation pathway. All of the benzyl $S_{N} 2 \Delta G^{\neq}$values for the double-meta substitutions with electron-donating substituent groups are larger than the unsubstituted
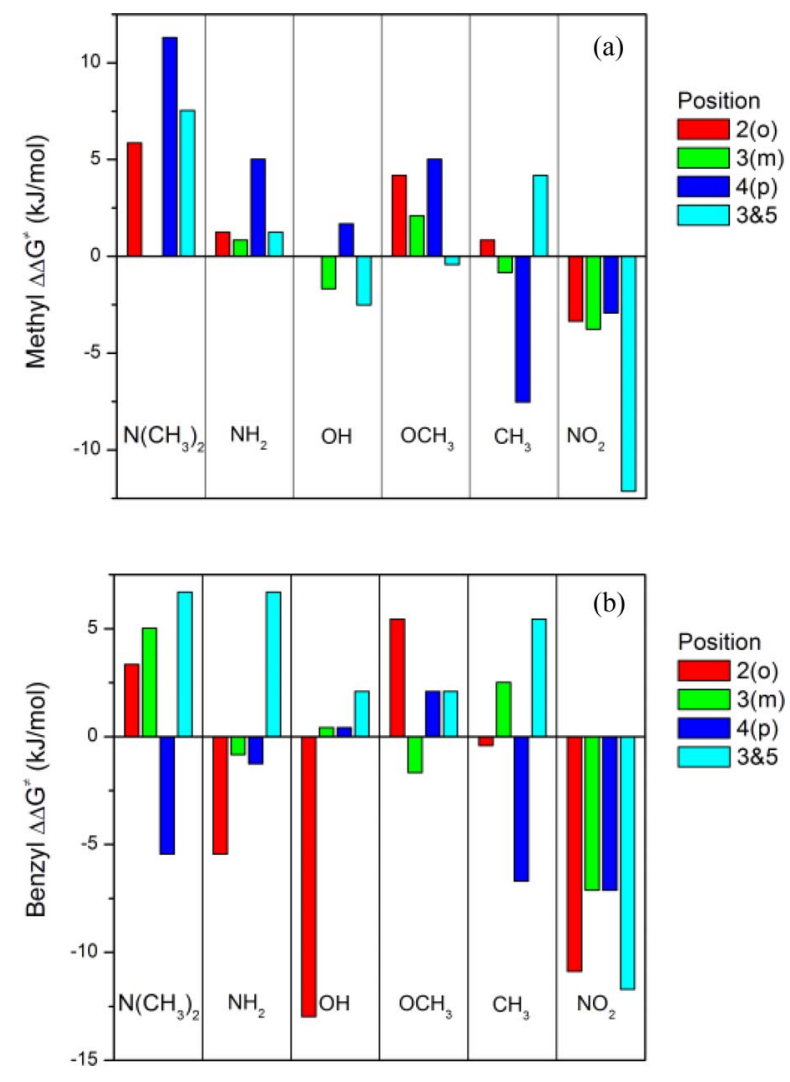

Figure 2. $\Delta \Delta \mathrm{G}^{\neq}$values of (a) methyl $\mathrm{S}_{\mathrm{N}} 2$ and (b) benzyl $\mathrm{S}_{\mathrm{N}} 2$ for the substituted $\mathrm{BTMA}^{+}$cations at $160^{\circ} \mathrm{C}$ and $101.325 \mathrm{kPa}$.
$\mathrm{BTMA}^{+}$, indicating that this type of substitutions is beneficial for its slightly increased stability.

Benzyl $S_{N} 2 \Delta G^{\neq}$and Hammett substituent constants.- According to the TS theory,

$$
\log \left(k / k_{0}\right)=-\Delta \Delta G^{\neq} /(2.303 R T)
$$

where $R$ is the gas constant, $T$ is the temperature, $k$ and $k_{0}$ are the degradation reaction rate constants of the unsubstituted and substituted $\mathrm{BTMA}^{+}$cations, respectively. The correlation between $k$ and the type of substituent groups could be described empirically by the Hammett equation, where $\log (k)$ has a linear relationship with the Hammett substituent constants $\sigma .^{23,24}$ Values of $\sigma$ depend on the substituent groups and the substitution positions. It has been reported that hydroxide degradation of substituted quaternary phosphonium cations showed a linear relationship between $\log \left(k / k_{0}\right)$ and $\sigma$ with a slope of 3.64. ${ }^{25}$ Encouraged by this research that showed a change of stability of 4 orders of magnitude in stability between singly substituted phosphoium ions, we employed a similar approach to search for substituent groups that might result in improved degradation barriers. For the neutral para substitutions, when the reaction TS structure has positive or negative charges, $\sigma_{\text {para }}{ }^{+}$or $\sigma_{\text {para }}{ }^{-}$values should be used instead of $\sigma_{\text {para }}{ }^{24}$ Table $S 1$ presents the Hammett substituent constants compiled by Hansch et $\mathrm{al}^{24}$ for the substituents investigated in the previous section and Fig. S2 and S3 illustrate the plots of $\log \left(k / k_{0}\right)$ vs. $\sigma$.

For the meta substitutions, the benzyl $S_{N} 2 \log \left(k / k_{0}\right)$ vs. $\sigma_{\text {meta }}$ plot (Fig. S2a) shows a linear relationship. The linear regression analysis results in a slope of 1.3 with the coefficient of determination $R=0.87$. The difference in the slopes of substituted $\mathrm{BTMA}^{+}$and substituted quaternary phosphonium may be the result of different electronic effects between the two types of cations, although further experimental validation (work is already underway) is still required for the BTMA ${ }^{+}$ cations reported here. For the double-meta substitutions (Fig. S2b), the slope is 2.5 , almost double the values of the single-meta substitutions, indicating that double-meta substitutions result in a stronger stabilization effect (or destabilization effect for $-\mathrm{NO}_{2}$ ) from the substituent groups. The $R$-value for this fit is 0.97 , showing a much better linear relationship than the single-meta substitution case. Still, the impact on stability is far less than the singly substituted phosphonium ions reported by McEwen et al. ${ }^{25}$

For the para substitutions, the benzyl $S_{N} 2 \log \left(k / k_{0}\right)$ vs. $\sigma_{\text {para }}$ plot (Fig. S3a) shows no linear relationship. Because the cations are charged, plots for $\log \left(k / k_{0}\right)$ vs. $\sigma_{\text {para }}{ }^{+}$(Fig. S3b) and $\log \left(k / k_{0}\right)$ vs. $\sigma_{\text {para }}{ }^{-}$(Fig. S3c) were also explored. Only the $\sigma_{\text {para }}{ }^{-}$plot shows a somewhat linear relationship but two data points are still far from the trend line. The TS structure of the benzyl $S_{\mathrm{N}} 2$ reaction for the BTMA ${ }^{+}$ cation is neutral and the cation is positively charged. This case is similar to the reaction with a negatively charged TS structure and a neutral reactant, in which the TS structure has more negative charge than the reactant, which may be the reason that the $\sigma_{\text {para }}{ }^{-}$results in the best linear relationship. If the two data points far from the trend line are omitted, a slope of 0.6 is obtained from the linear regression with $R=$ 0.95 . This low slope is indicative of a very minor impact on stability through para substitution.

Multivalent $B T M A^{ \pm}$. - The substituent group itself could have positive charges, resulting in a multivalent cation. The benzyl $\mathrm{S}_{\mathrm{N}} 2$ $\Delta \Delta \mathrm{G}^{\neq}$of $-\mathrm{CH}_{2} \mathrm{~N}^{+}\left(\mathrm{CH}_{3}\right)_{3}$ substituted $\mathrm{BTMA}^{+}$cations was calculated as an example. The ortho, meta, and para substitutions have benzyl $\mathrm{S}_{\mathrm{N}} 2 \Delta \Delta \mathrm{G}^{\neq}$values of $-7.5 \mathrm{~kJ} / \mathrm{mol},-14.2 \mathrm{~kJ} / \mathrm{mol}$ and $-5.0 \mathrm{~kJ} / \mathrm{mol}$ respectively, when compared to the unsubstituted $\mathrm{BTMA}^{+}$cation. Obviously, substituted $\mathrm{BTMA}^{+}$cations with multiple-charge centers will have smaller $\Delta \mathrm{G}^{\neq}$values than the unsubstituted $\mathrm{BTMA}^{+}$due to the strong electron withdrawing nature of multiple cationic sites.

Double-meta substitutions by $-N R R^{\prime}$. - Encouraged by the large benzyl $\mathrm{S}_{\mathrm{N}} 2 \Delta \Delta \mathrm{G}^{\neq}$values of $-\mathrm{NH}_{2}$ and $-\mathrm{N}\left(\mathrm{CH}_{3}\right)_{2}$, we further investigated substituent groups in $-\mathrm{NRR}^{\prime}$ form at meta and double-meta 
Table II. Benzyl $S_{\mathrm{N}} 2 \Delta G^{\neq}$values in $\mathrm{kJ} / \mathrm{mol}$ of benzyl $S_{\mathrm{N}} 2 /$ methyl $\mathrm{S}_{\mathrm{N}} 2$ for $-\mathrm{NRR}^{\prime}$ substituted $\mathrm{BTMA}^{+}$cations at $160^{\circ} \mathrm{C}$ and $101.325 \mathrm{kPa}$.

\begin{tabular}{lccc} 
& & $\begin{array}{c}3 \text {-substitution } \\
\Delta \mathrm{G}^{\neq}\end{array}$ & $\begin{array}{c}3 \& 5 \text { substitution } \\
\Delta \mathrm{G}^{\neq}\end{array}$ \\
\hline$-\mathrm{N}\left(\mathrm{CH}_{2} \mathrm{CH}_{3}\right)_{2}$ & -0.23 & $101.7 / 114.6$ & $102.9 / 110.0$ \\
$-\mathrm{N}\left(\mathrm{CH}_{2} \mathrm{CH}_{2} \mathrm{CH}_{3}\right)_{2}$ & -0.26 & $100.0 / 107.5$ & $102.1 / 107.5$ \\
$-\mathrm{NH}\left(\mathrm{CH}_{3}\right)$ & -0.21 & $100.4 / 109.6$ & $102.1 / 109.2$ \\
$-\mathrm{NH}\left(\mathrm{CH}_{2} \mathrm{CH}_{2} \mathrm{CH}_{2} \mathrm{CH}_{3}\right)$ & -0.34 & $101.3 / 107.5$ & $102.5 / 108.4$
\end{tabular}

positions. Four substituent groups with large negative $\sigma_{\text {meta }}$ values were studied and we expected them to have improved degradation barriers. The four substituent groups are: $-\mathrm{N}\left(\mathrm{CH}_{2} \mathrm{CH}_{3}\right)_{2}$, $-\mathrm{N}\left(\mathrm{CH}_{2} \mathrm{CH}_{2} \mathrm{CH}_{3}\right)_{2}, \quad-\mathrm{NH}\left(\mathrm{CH}_{3}\right)$, and $-\mathrm{NH}\left(\mathrm{CH}_{2} \mathrm{CH}_{2} \mathrm{CH}_{2} \mathrm{CH}_{3}\right)$. Table II presents their $\sigma_{\text {meta }}$ values ${ }^{24}$ and calculation results. Although the four substituent groups all show some improvement when compared to the unsubstituted $\mathrm{BTMA}^{+}$, none of them have a benzyl $\mathrm{S}_{\mathrm{N}} 2$ $\Delta \mathrm{G}^{\neq}$larger than the $104.2 \mathrm{~kJ} / \mathrm{mol}$ barrier observed for double-meta $-\mathrm{N}\left(\mathrm{CH}_{3}\right)_{2}$. Fig. S4 shows that the corresponding four data points are overlaid on the plots of Fig. S2. Although these points still follow the trend lines, in some cases, the deviations from the trend lines are more than half magnitude. This suggests that Hammett substituent constants could be used to roughly predict the benzyl $\mathrm{S}_{\mathrm{N}} 2 \Delta \mathrm{G}^{\neq}$. However, further increasing stability through substitution seems unlikely due to the high Hammett values of the substituents already investigated.

$S_{N} 1$ pathway.- Besides the benzyl and methyl $\mathrm{S}_{\mathrm{N}} 2$ pathways, BTMA $^{+}$may also take the benzyl $\mathrm{S}_{\mathrm{N}} 1$ pathway,

$$
\mathrm{X}-\mathrm{C}_{6} \mathrm{H}_{4} \mathrm{CH}_{2} \mathrm{~N}^{+}\left(\mathrm{CH}_{3}\right)_{3}=\mathrm{X}-\mathrm{C}_{6} \mathrm{H}_{4} \mathrm{CH}_{2}{ }^{+}+\mathrm{N}\left(\mathrm{CH}_{3}\right)_{3} \text {, }
$$

$$
\mathrm{X}-\mathrm{C}_{6} \mathrm{H}_{4} \mathrm{CH}_{2}{ }^{+}+\mathrm{OH}^{-}=\mathrm{X}-\mathrm{C}_{6} \mathrm{H}_{4} \mathrm{CH}_{2} \mathrm{OH}
$$

and the methyl $\mathrm{S}_{\mathrm{N}} 1$ pathway,

$$
\mathrm{X}-\mathrm{C}_{6} \mathrm{H}_{4} \mathrm{CH}_{2} \mathrm{~N}^{+}\left(\mathrm{CH}_{3}\right)_{3}=\mathrm{X}-\mathrm{C}_{6} \mathrm{H}_{4} \mathrm{CH}_{2} \mathrm{~N}\left(\mathrm{CH}_{3}\right)_{2}+\mathrm{CH}_{3}{ }^{+} \text {, }
$$

$$
\mathrm{CH}_{3}{ }^{+}+\mathrm{OH}^{-}=\mathrm{CH}_{3} \mathrm{OH}
$$

where $\mathrm{X}$ is the substituent group. For the unsubstituted $\mathrm{BTMA}^{+}$, these degradation pathways were not investigated in previous reports because reaction barriers for reactions $4 \mathrm{a}$ and $5 \mathrm{a}$ are very high in aqueous solution owing to the formation of the highly unstable $\mathrm{CH}_{3}{ }^{+}$and $\mathrm{C}_{6} \mathrm{H}_{5} \mathrm{CH}_{2}{ }^{+}$cations. However, when there are one or more electrondonating substituent groups on the benzyl ring, the $\mathrm{X}-\mathrm{C}_{6} \mathrm{H}_{4} \mathrm{CH}_{2}{ }^{+}$ cation is stabilized, which may result in a lower reaction barrier for reaction $4 a$. Table III presents the benzyl $S_{N} 1 \Delta G^{\neq}$of select cations. For the unsubstituted BTMA ${ }^{+}$, benzyl $\mathrm{S}_{\mathrm{N}} 1 \Delta \mathrm{G}^{\neq}$is $138.9 \mathrm{~kJ} / \mathrm{mol}$, much larger than the benzyl $S_{N} 2 \Delta G^{\neq} 97.5 \mathrm{~kJ} / \mathrm{mol}$. This is consistent with the conclusion that the benzyl $\mathrm{S}_{\mathrm{N}} 2$ pathway is the dominant degradation pathway for unsubstituted $\mathrm{BTMA}^{+} .{ }^{18,20,26,27}$ For the double-meta $-\mathrm{OCH}_{3}$ substitution, the benzyl $\mathrm{S}_{\mathrm{N}} 1 \Delta \mathrm{G}^{\neq}$is $136.4 \mathrm{~kJ} / \mathrm{mol}$, close to the value of the unsubstituted BTMA ${ }^{+}$. For the double-meta $-\mathrm{N}\left(\mathrm{CH}_{3}\right)_{2}$ substitution, the benzyl $\mathrm{S}_{\mathrm{N}} 1 \Delta \mathrm{G}^{\neq}$is $115.9 \mathrm{~kJ} / \mathrm{mol}$, still larger than its benzyl $S_{N} 2 \Delta G^{\neq}(104.2 \mathrm{~kJ} / \mathrm{mol})$, although the gap between $S_{N} 1$ $\Delta \mathrm{G}^{\neq}$and $\mathrm{S}_{\mathrm{N}} 2 \Delta \mathrm{G}^{\neq}$is much smaller. The stabilization effect is much

Table III. $\Delta G^{\neq}$values in $\mathrm{kJ} / \mathrm{mol}$ of benzyl $S_{N} 1$ and $S_{N} 2$ pathways for the unsubstituted and select substituted BTMA $^{+}$cations at $160^{\circ} \mathrm{C}$ and $101.325 \mathrm{kPa}$.

No

substitution $-\mathrm{OCH}_{3}-\mathrm{N}\left(\mathrm{CH}_{3}\right)_{2}-\mathrm{N}\left(\mathrm{CH}_{3}\right)_{2}-\mathrm{OCH}_{3}$

\begin{tabular}{cccccc} 
& substitution & $-\mathrm{OCH}_{3}$ & $-\mathrm{N}\left(\mathrm{CH}_{3}\right)_{2}$ & $-\mathrm{N}\left(\mathrm{CH}_{3}\right)_{2}$ & $-\mathrm{OCH}_{3}$ \\
\hline Position & N/A & $3 \& 5$ & $3 \& 5$ & 4 & $2 \& 6$ \\
Benzyl $\mathrm{S}_{\mathrm{N}} 1 \Delta \mathrm{G}^{\neq}$ & 138.9 & 136.4 & 115.9 & 47.3 & 86.2 \\
Benzyl $\mathrm{S}_{\mathrm{N}} 2 \Delta \mathrm{G}^{\neq}$ & 97.5 & 99.6 & 104.2 & 92.0 & 100.8
\end{tabular}

stronger for electron-donating substituents at ortho and para positions. The para $-\mathrm{N}\left(\mathrm{CH}_{3}\right)_{2}$ has a benzyl $\mathrm{S}_{\mathrm{N}} 1 \Delta \mathrm{G}^{\neq}$as small as $47.3 \mathrm{~kJ} / \mathrm{mol}$, much smaller than its benzyl $\mathrm{S}_{\mathrm{N}} 2 \Delta \mathrm{G}^{\neq}, 92.0 \mathrm{~kJ} / \mathrm{mol}$. For the doubleortho $-\mathrm{OCH}_{3}$ substitution, it has a relative large benzyl $\mathrm{S}_{\mathrm{N}} 2 \Delta \mathrm{G}^{\neq}$, $100.8 \mathrm{~kJ} / \mathrm{mol}$, but its benzyl $\mathrm{S}_{\mathrm{N}} 1 \Delta \mathrm{G}^{\neq}$is only $86.2 \mathrm{~kJ} / \mathrm{mol}$. In both cases, the benzyl $\mathrm{S}_{\mathrm{N}} 1$ pathway becomes the dominant degradation pathway, and thus, the rate-limiting step for the degradation. Therefore, in search of the $\mathrm{BTMA}^{+}$derivative cations with high stability, meta substitutions with electron-donating substituents are preferred, not only because meta substitutions have larger benzyl $S_{N} 2 \Delta G^{\neq}$, but also because ortho and para substitutions may result in the benzyl $\mathrm{S}_{\mathrm{N}} 1$ pathway becoming the dominant, low energy barrier degradation pathway.

\section{Conclusions}

According to our calculation results, we concluded that the methyl $\mathrm{S}_{\mathrm{N}} 2$ pathway is not the rate-limiting step of degradation for substituted BTMA $^{+}$cations. Double-meta substitutions with electron-donating substituent groups are predicted to result in limited improved stability for the benzyl $S_{N} 2$ pathway. On the other hand, positively charged and electron-withdrawing substituent groups decrease the stability of cations. For cations with electron-donating substituents, especially for those with substituents at ortho and para positions, the barrier for the benzyl $\mathrm{S}_{\mathrm{N}} 1$ pathway could be low enough to become the rate-limiting step. In addition, Hammett substituent constants were found able to qualitatively predict the calculated degradation barriers.

It should be noted that some of the substituted BTMA ${ }^{+}$cations would be very difficult (or impossible) to synthesize and/or purify experimentally (e.g., $-\mathrm{OH},-\mathrm{NH}_{2}$, or $\left.-\mathrm{NRR}^{\prime}\right)$. The most important finding of this computational work, however, is that substituted BTMA ${ }^{+}$ cations show less than one order of magnitude improvement on stability. Although degradation barriers for more than thirty cations with ten different substituent groups have been investigated in this work, the cation with the largest improvement found, i.e., the cation with double-meta $-\mathrm{N}\left(\mathrm{CH}_{3}\right)_{2}$, only has a $\Delta \Delta \mathrm{G}^{\neq}$of $6.7 \mathrm{~kJ} / \mathrm{mol}$ at $160^{\circ} \mathrm{C}$. At a temperature of $80^{\circ} \mathrm{C}$, which is the typical working temperature of a fuel cell, our calculation shows that its $\Delta \Delta \mathrm{G}^{\neq}$is $6.3 \mathrm{~kJ} / \mathrm{mol}$. According to Eq. 3, this will result in a decrease in degradation rate of 8.5 times at $80^{\circ} \mathrm{C}$. This is a potentially meaningful improvement in degradation rate, and may be critically important for some applications. However, these materials still show susceptibility to hydroxide attack and will likely be insufficient for a number of applications. These results are of most interest to the AEM community when viewed in terms of the potential of $\mathrm{BTMA}^{+}$cations to meet required durability under operating conditions.

While these results still require experimental validation that we are currently undertaking, they suggest other types of cations will need to be investigated for larger increases in stability. A number of groups are investigating other cation families, and increased hydroxide stability of AEMs is looking much more promising at this time. As an example, our recent calculation results indicated that substituted imidazolium cations may have several magnitudes of improvement of stability over $\mathrm{BTMA}^{+}$cation and offer greatly enhanced stability compared to $\mathrm{BTMA}^{+}$derivative cations. ${ }^{28}$

\section{Acknowledgments}

This work was supported by the U.S. Department of Energy (DOE), Office of Basic Energy Sciences, Division of Materials Science and Engineering, under Contract No. DE-AC36-08-GO28308. This research used capabilities of the National Renewable Energy Laboratory Computational Science Center, which is supported by the Office of Energy Efficiency and Renewable Energy of DOE.

\section{References}

1. J. M. Andujar and F. Segura, Renew. Sust. Energ. Rev., 13(9), 2309 (2009).

2. E. Gulzow, J. Power Sources, 61(1-2), 99 (1996). 
3. E. Gulzow and M. Schulze, J. Power Sources, 127(1-2), 243 (2004).

4. G. F. McLean, T. Niet, S. Prince-Richard, and N. Djilali, Int. J. Hydrogen Energ., 27(5), 507 (2002)

5. J. R. Varcoe and R. C. T. Slade, Fuel Cells, 5(2), 187 (2005).

6. G. Couture, A. Alaaeddine, F. Boschet, and B. Ameduri, Prog. Polym. Sci., 36(11), 1521 (2011).

7. C. S. Macomber, J. M. Boncella, B. S. Pivovar, and J. A. Rau, J. Therm. Anal. Calorim., 93(1), 225 (2008).

8. J. B. Edson, C. S. Macomber, B. S. Pivovar, and J. M. Boncella, J. Membr. Sci., 399-400, 49 (2012)

9. J. R. Varcoe, R. C. T. Slade, and E. Lam How Yee, Chem. Commun., (13), 1428 (2006).

10. B. R. Einsla, S. Chempath, L. R. Pratt, J. R. Boncella, C. Macomber, and B. S. Pivovar, ECS Trans., 11(1), 1173 (2007).

11. E. N. Komkova, D. F. Stamatialis, H. Strathmann, and M. Wessling, J. Membr. Sci., 244(1-2), 25 (2004).

12. O. I. Deavin, S. Murphy, A. L. Ong, S. D. Poynton, R. Zeng, H. Herman, and J. R. Varcoe, Energ. Environ. Sci., 5(9), 8584 (2012).

13. C. G. Arges, J. Parrondo, G. Johnson, A. Nadhan, and V. Ramani, J. Mater. Chem. 22(9), 3733 (2012).

14. C. G. Arges and V. Ramani, J. Electrochem. Soc., 160(9), F1006 (2013).
15. C. G. Arges and V. Ramani, P. Natl. Acad. Sci. USA, 110(7), 2490 (2013).

16. C. Fujimoto, D. S. Kim, M. Hibbs, D. Wrobleski, and Y. S. Kim, J. Membr. Sci., 423, 438 (2012).

17. M. R. Sturgeon, C. S. Macomber, C. Engtrakul, and B. S. Pivovar, ECS Trans., 64(3), 1201 (2014)

18. S. Chempath, J. M. Boncella, L. R. Pratt, N. Henson, and B. S. Pivovar, J. Phys. Chem. C, 114(27), 11977 (2010).

19. S. Chempath, B. R. Einsla, L. R. Pratt, C. S. Macomber, J. M. Boncella, J. A. Rau, and B. S. Pivovar, J. Phys. Chem. C, 112(9), 3179 (2008).

20. H. Long, K. Kim, and B. S. Pivovar, J. Phys. Chem. C, 116(17), 9419 (2012).

21. M. J. Frisch, G. W. Trucks, H. B. Schlegel, G. E. Scuseria, M. A. Robb, J. R. Cheeseman, G. Scalmani, V. Barone, B. Mennucci, and G. A. Petersson et al, Gaussian, Inc., Gaussian 09, Revision A.02, Wallingford CT, (2009).

22. A. D. Becke, J. Chem. Phys., 98(7), 5648 (1993).

23. L. P. Hammett, J. Am. Chem. Soc., 59(1), 96 (1937)

24. C. Hansch, A. Leo, and R. W. Taft, Chem. Rev., 91(2), 165 (1991).

25. W. E. McEwen, G. Axelrad, M. Zanger, and C. A. VanderWerf, J. Am. Chem. Soc., 87, 3948 (1965).

26. E. W. Baumann, J. Chem. Eng. Data, 5(3), 376 (1960).

27. M. J. Hatch and W. D. Lloyd, J. Appl. Polym. Sci., 8(4), 1659 (1964).

28. H. Long and B. S. Pivovar, J. Phys. Chem. C, 118(19), 9880 (2014). 